\title{
The impact and challenges of sustainable biogas implementation: moving towards a bio-based economy
}

\author{
Ralph Muvhiiwa*, Diane Hildebrandt, Ngonidzashe Chimwani, Lwazi Ngubevana and Tonderayi Matambo
}

\begin{abstract}
Background: Engineers face increasing pressure to manage and utilize waste (whether of animal, human or municipal origin) in a sustainable way. We suggest that a solution to the problem of organic waste in rural communities lies in their being able to convert it to biogas technology. This would offer smallholders and farmers a long-term, cheap and sustainable energy source that is independent of the national electricity grid. However, although the technology involved in making biogas from waste has already been fully developed, there are obstacles impeding its adoption. First, there is a general ignorance about this source of energy among the very people who can most benefit from using it. Second, at present, South Africa has no regulatory framework to support the installation of biodigesters.
\end{abstract}

Methods: The research focused on the current gap between knowledge and need. The two objectives were raising general awareness of the many and varied benefits that biodigestion can offer, especially to rural communities, and demonstrating how it works. Using science events as a platform, the team introduced the concept of biodigestion, its functioning and uses, to their audiences, and then invited informal responses, which were recorded. The second stage, the case study, entailed the setting up of a small-scale $\left(10 \mathrm{~m}^{3}\right)$ household biodigester in the Muldersdrift community in Gauteng, South Africa. It was put into operation, using fresh cow dung as the feed. Members of the community were invited to watch every step of the process and afterwards were asked to participate in a more formal survey, which sought their opinions on whether biodigestion offers a power source the individual farmer could (and would) use.

Results: The results presented in this paper were derived from a comparison of the 'before-and-after-installation' responses of the persons interviewed. We found that the members of the Muldersdrift community who had been involved in both phases of the case study (explanation followed by experience of a hands-on educational example) had become more willing to adopt the technology.

Conclusions: The results justified our contention that, to ensure a greater adoption of biogas technology in South Africa, it is necessary to provide targeted communities with educational programmes and exposure to pilot plants.

Keywords: Biogas sustainability, Community engagement, Methane, Rural areas, Small-scale farms

\section{Background}

Although conversion of waste to biogas is an established technology, it has been under-used, probably because until recently, electricity was relatively affordable to most of the population in South Africa. However, the increase in both the demand for, and the cost of,

\footnotetext{
* Correspondence: r.muvhiiwa@gmail.com

Materials and Process Synthesis (MaPS) and Engineers Without Borders (EWB)-Unisa, College of Science, Engineering and Technology, University of South Africa (UNISA), c/o Christiaan de Wet \& Pioneer Avenue, Florida Campus 1710, Johannesburg, South Africa
}

electricity has prompted engineers to revive their interest in rolling out biogas technology in South Africa [1].

A salient reason for advocating biodigestion as an alternative source of energy is that electricity is not available in all parts of this country. Approximately 2.328 million households, estimated by Triebel and Damm [2] as representing 25-30\% of South African families, meet their energy needs with traditional fuels such as firewood and charcoal. Most of this group live in deprived circumstances in the urban slums and rural areas but have no knowledge of biogas technology. 
The overarching purpose of the Materials and Process Synthesis (MaPS) team's research during this project was to test the hypothesis that if biogas can be fully exploited, it can supply a means of overcoming energy poverty in rural South Africa.

The authors reasoned that in order to introduce biogas to South Africans who lack access to a power supply, the first requirement must be to introduce them to the concept of biogas, and the second to teach them how the technology works. They started the process by identifying rural communities that did not have access to electricity, with a view to introducing them to the nature and functioning of biodigesters. A collaborative approach was applied throughout, and community members were asked for their views and queries about biodigestion both before and after the pilot digester had been commissioned.

It is worth noting that our project was in alignment with South Africa's Development Plan (NDP) and bio-economy strategy, which aim to promote bio-innovations to achieve a sustainable economy based on biological resources, materials and processes. The production of biogas is also synchronous with the United Nations Sustainable Development Goals (SDG), especially goal numbers 1 and 7, which require that this technology can help reduce socioeconomic poverty by providing clean energy that from renewable sources. South Africa is also signatory to the Kyoto protocol, which undertakes to cut greenhouse gas emissions back by $34 \%$ by 2020 and $45 \%$ by 2030 [3].

\section{Biogas as an energy solution to rural South African communities}

Due to the current energy shortages and cost of raising capital in South Africa, it is likely that the national power supply company (ESKOM) will be unable to continue expanding its network into the rural areas. This has given impetus to the search for alternative energy sources. Biogas offers a cheap, renewable and viable solution to the problem of providing energy to rural communities and farmers [4] and also has the merit of using waste that has been traditionally regarded as useless, as the feedstock.

The technology involved in biogas production is fairly simple and can be implemented cheaply and efficiently by means of small-scale digesters that are easy to use and maintain. These household biodigesters can offer benefits to all spheres of society but have a particular bearing on the needs of farmers in rural areas. They can use the gas produced for cooking and lighting, for charging batteries from running biogas generators, and for fertilizing crops with the residual waste.

Another reason for identifying this group as most suitable for putting the biodigestion technology into practice is that small farmers generally have free access to livestock waste, which provides feedstock for the digester.
Normally, rural households use the raw manure obtained from their animals as a form of plant fertilizer, but this has a lower organic nitrogen content than the slurry created by the biogas digestion process [5-7], which is odourless, and makes a better fertilizer.

Also, the combustion of biogas provides a clean source of energy, as it does not produce soot, like firewood. This helps reduce indoor air pollution, which in turn prevents respiratory infections and associated diseases [8]. According to an evaluation by Pal [9] in India, a biogas digester producing $2 \mathrm{~m}^{3}$ of biogas per day can replace approximately $270-300 \mathrm{~kg}$ of firewood per month, depending on the quality of the biogas. Studies of the domestic use of biogas carried out in rural areas in Zimbabwe and Kenya [10,11] also found that using biogas for cooking was more time-efficient than conventional fuels, and this was a key factor in the willingness of people to adopt it. Although time is required to collect waste and feed the digester, it is a much shorter period than the equivalent required to gather firewood and charcoal.

Perhaps, the most important of its many advantages is that biogas can offer a decentralized energy solution to rural communities in South Africa.

\section{The barriers to expansion and acceptance of biogas production in South Africa}

There are currently around 700 biodigesters in South Africa [4]. About $50 \%$ of these are small-scale domestic digesters, and only $10 \%$ are commercial installations [4]. The remaining numbers, representing approximately $40 \%$ are installed at wastewater treatment plants. There is still much room for further expansion, but various difficulties, not connected with the technology as such, impede it. The political and regulatory aspects of making access to biodigestion possible in South Africa are discussed briefly in a later section.

The focus of this article is on a key issue discussed during the National Biogas Conference, hosted by the Southern African Biogas Industry Association (SABIA) on 5 March 2015: the lack of awareness and understanding of biogas as a form of energy in the general public, which hinders the expansion of this technology in this country [12]. It was this point on which the project carried out was based.

Currently, most people who have the raw materials readily available do not have any knowledge of biogas technology. It is therefore important to educate them by first explaining and then demonstrating this technology to rural communities. This would allow the team to deal with some misconceptions that smallholders and farmers might have about biogas, increase their understanding of the technology, and consequently enable them to realize the benefits offered by it. Their acceptance of its 
usefulness is essential to their willingness to adopt biogas as a source of energy.

It is very difficult to devise a strategy with which to approach communities if the promoters have no understanding of the pre-perceptions and concerns of the farmers themselves. For similar reasons, the uptake of biodigesters in other African countries is not high. In Kenya, biogas technology is not new, but the adoption process is still slow, owing to inadequate funds, poor infrastructure and a general ignorance of this technology among the people who might derive the greatest benefit from it [11].

For all of the above reasons, the project designed by our team entailed two steps that would enable us to understand better how to increase the acceptance of biodigester technology within rural communities in South Africa. The first was to establish the level of knowledge about biogas technology in schools and rural areas. The second was to examine the differences in the views and responses of members of a rural community after the installation of a biodigester in their vicinity. A smallscale bag digester (approximately $10 \mathrm{~m}^{3}$ in volume was set up in the Muldersdrift community by a team from Engineers without Borders, based at the University of South Africa (EWB-Unisa). The feedstock for the biodigester was fresh cow dung. The performance of the biodigester was rated according to the typical energy requirements of a household, such as gas cooking, lighting, and heating water.

\section{Methods}

\section{Survey methodology}

The first, informal survey followed a qualitative approach because the team wanted to gather information on which they could base and interpret the quantitative approach used in the second survey [13-16]. The first was based on the spontaneous responses of participants in the science conferences to the concept [17]. (This type of approach allows the researcher to focus his or her efforts on gathering rich data from answers to the research questions). The second, more formal survey focused on the actual experience of smallholders and farmers witnessing the installation of the biodigester, the way it worked, and their assessment of its utility.

\section{Step 1: Survey of perceptions concerning biogas technology}

In order to understand the level of knowledge communities in South Africa have on biodigester technologies, the writers took part in four of the country's biggest science events, including "The Science Festival Africa" in Grahamstown and "The Sasol Expo" in Sasolburg, within the space of 2 years (2015-2016). The conferences were mainly held in small towns, located in predominantly rural and agricultural areas. The exception was Sasolburg, which is part of the so-called Vaal Triangle, which is highly industrialized, but is surrounded by agricultural land. Many people, largely comprising school pupils, members of the surrounding farmers, attended these events. At all of these, a simple cardboard model of a biodigester (shown in Fig. 1) was used to introduce those present to the nature and function of biogas and to invite their feedback. The purpose was to elicit what knowledge they had of biogas, their perceptions concerning it, and how safe they thought it was. There was no set questionnaire: it was an informal survey to determine people's responses to the idea of biogas. The researchers were particularly interested in finding out whether they were aware of biogas technology and its uses, and, if so, what level of understanding they had achieved. For those who had never come across the concept, we questioned them to gauge their reactions to it. Our central objective was to find out whether, or under what circumstances, they would embrace the idea of biodigestion. This approach is also very similar to the process synthesis approach used in chemical engineering to identify the most important factors in a complex system relatively quickly [18].

While step one involved ascertaining the knowledge of biogas technology in attendees at the science events, step two entailed a practical demonstration of how the technology works. The team did this by involving some members of the local farming community in the building and commissioning of a pilot biodigester.

\section{Step 2: Case study_implementing biogas technology in a rural/farming South African community Case study location}

The researchers from the team had met a small-scale farmer in Mulderdrift when they were looking for manure for their laboratory experiments on anaerobic digestion to produce biogas. He had shown interest in what they were doing, as he had never heard of biogas before. Over time, he became familiar with the team and the work they were doing and was very enthusiastic about seeing how a digester, built on his land, would work in practice.

A small-scale biodigester was built by the EWB team on a small farm in Muldersdrift, on the outskirts of Johannesburg. The area surrounding the location of the biogas plant comprises both agricultural plots and farms, and it was from a catchment area within an approximately $3-\mathrm{km}$ radius of the plot on which the digester was to be built that we recruited local people, mainly farmers and farm workers, who were willing to participate in our study. No specific criterion was used to pick those surveyed, and the general answers we were given by the respondents were obtained through informal conversations/purposive sampling. These are shown in a 


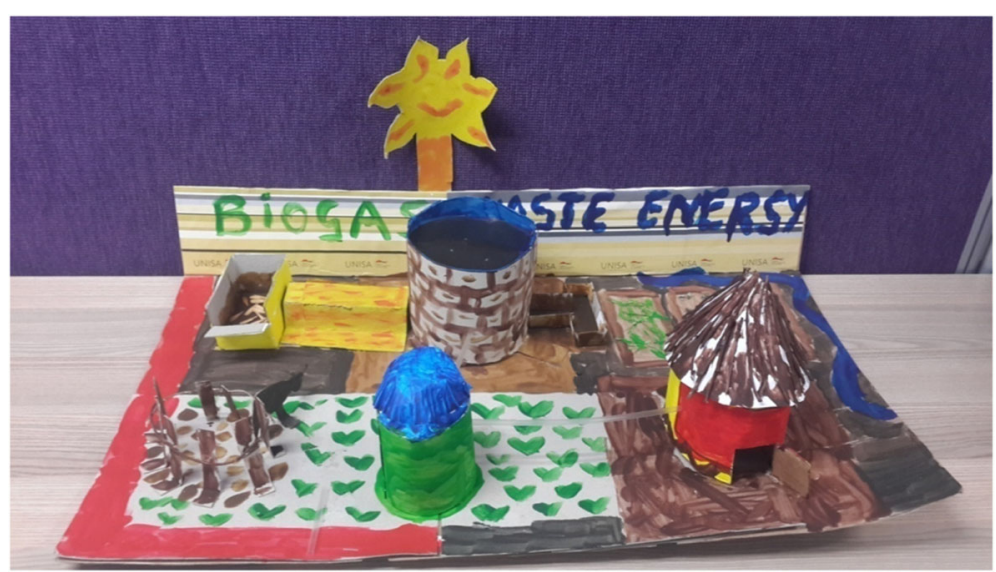

Fig. 1 Simple display used by EWB-Unisa at the Science Expos to discuss biogas technology

later section of this research paper, when the "before" and "after" stages of the surveys are compared.

\section{The design and implementation of the biodigester}

The biodigester chosen for the Muldersdrift experiment was of the biobag variety because it is more easy to maintain than a fixed dome brick digester. The design used a large biobag (made of durable reinforced and bacteria-resistant polyvinyl chloride (PVC) which can have a lifespan of more than 15 years). The biodigester is $8 \mathrm{~m}$ long and has a diameter of $1 \mathrm{~m}$. Two manholes were constructed, using cement bricks to form the biodigester inlet and outlet. The digester (PVC) bag was then connected to the inlet and outlet using $25-\mathrm{cm}$ diameter PVC piping. The biodigester bag was placed in a trench that slopes slightly downward from inlet to outlet so that the inlet pipe was placed $20 \mathrm{~cm}$ higher than the outlet pipe. This was necessary for two reasons: the biodigester operates by means of gravity displacement; and also the difference in height forms a liquid seal preventing air from entering through the inlet pipe into the biodigester. This system is simple to construct, when compared with the conventional dome-shaped biodigester design. Another advantage of this type of biodigester is that the actual digester is made from light-weight PVC plastic, and the only major construction effort required is digging the manholes.

Once a digester has been installed, fresh animal dung is collected and mixed with water in a ratio of at least 1:4 by volume to form slurry. The cow dung is collected from a cattle kraal where the animals sleep at night, but graze on a free range paddock during the day. (Incidentally, a drawback of the biogas process is that it requires a lot of water.) Twenty litres of slurry is fed every 2 days to the biodigester. The digestion retention time is around 20-40 days, during which time the waste material is broken down by a consortium of the bacteria that occur naturally in the manure, to produce biogas (mainly methane and carbon dioxide) in the absence of oxygen. As the waste begins to digest, the biogas produced inflates the biobag, and the gas is released through a valve to piping that is connected to the appliances in the farmhouse. The gas passes through a pressure pump (alternatively some weights, typically old tyres, are placed on the biobag to build up a pressure of $2.5 \mathrm{KPa}$, which is the minimum needed by the biogas stove or lamp). The gas pipeline also passes through a moisture trap and a desulphurising unit, which can be made by using a container filled with iron filings. All these small units are needed before the gas can be used, but all are cheap to manufacture. The whole process is presented in Fig. 2, and a picture of the inflated bag is shown in Fig. 3.

The digester used was supplied by Biogas SA and (as already noted) is simple to install and operate. The cost of a full kit imported biobag was about ZAR16 000 (USD \$1120) in 2015/2016. Although this is a once-off cost, this amount is beyond the reach of many rural households. However, bricks can be moulded locally and if cement can be obtained, a cheaper type of digester can be built for a small household.

\section{Performance of the biodigester}

The biobag has a gas volume of about $4-5 \mathrm{~m}^{3}$, and its output comprises around $53 \%$ of methane gas concentrate and the remaining $47 \%$ of carbon dioxide available for use per day in summer, when the temperatures average $25-30{ }^{\circ} \mathrm{C}$. This gas can be used for a cooking for $2-3 \mathrm{~h}$ a day and provides about two plus hours a day of lighting (using a gas lamp). The farmer can also use the gas to run a $700 \mathrm{~W}$ biogas generator for an hour per day (he can use this for battery charging) as well as to heat water for bathing in a 7-1/min gas geyser. The amount of water heated was sufficient for the use of three adults. The digester is fed with a 201 amount of fresh waste 


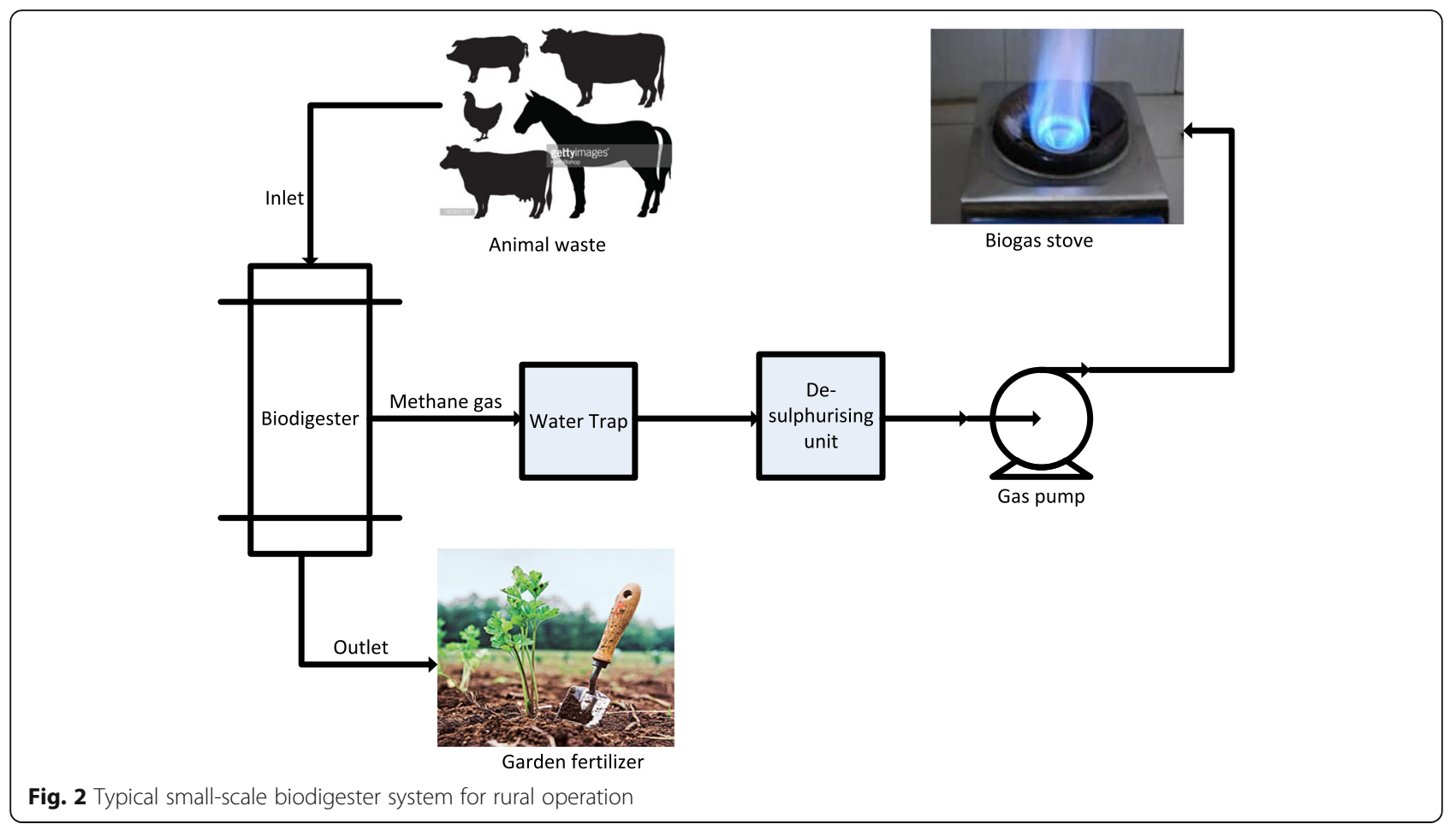

slurry every second day, which is enough to supply the gas requirements of the household. The use of biogas saves the farmer about $1 \mathrm{~h}$ per day, as he no longer has to spend time fetching and preparing firewood.

In winter, when temperatures are low $\left(\sim 15{ }^{\circ} \mathrm{C}\right)$, the range of usage becomes more limited, as the digester produces only enough gas for cooking. No gas is produced when there is frost $\left(<10{ }^{\circ} \mathrm{C}\right)$ because the activity of the methanogen (mesophiles) bacteria reduces with the drop in temperature and becomes completely inactive at temperatures lower than $10{ }^{\circ} \mathrm{C}$ [19]. The waste that is fed into the biobag during the coldest months can take up to 30 days to digest and produce gas so that the waste that the farmer feeds in today will produce usable gas only in about a month's time.

\section{Community survey after exposure to biogas technology}

Throughout the step-by-step construction and operation of the digester, we explained to the community members how the production of the biogas gas takes place, and the different ways in which it can be used. We made clear that although bacterial activity helped to produce the gas during the decomposition of waste materials, the resultant gas did not contain dangerous bacteria. After this two-phase introduction had been completed, most of the participants indicated that they would adopt the technology if it would save them more time and money than relying on traditional sources of energy.

The post-installation survey took the form of a qualitative, cross-sectional study with purposive sampling. The research data were obtained from about 25 people and took the form of a questionnaire that aimed to assess whether they had a basic knowledge of science, what they knew about biodigesters, and their attitude towards biodigester technology and science in general. None of the respondents to this survey had visited any of the Science Expos. We also looked at demographics concerning race, age and their rating according to the Living Standards Measure (LSM), which is commonly used in South

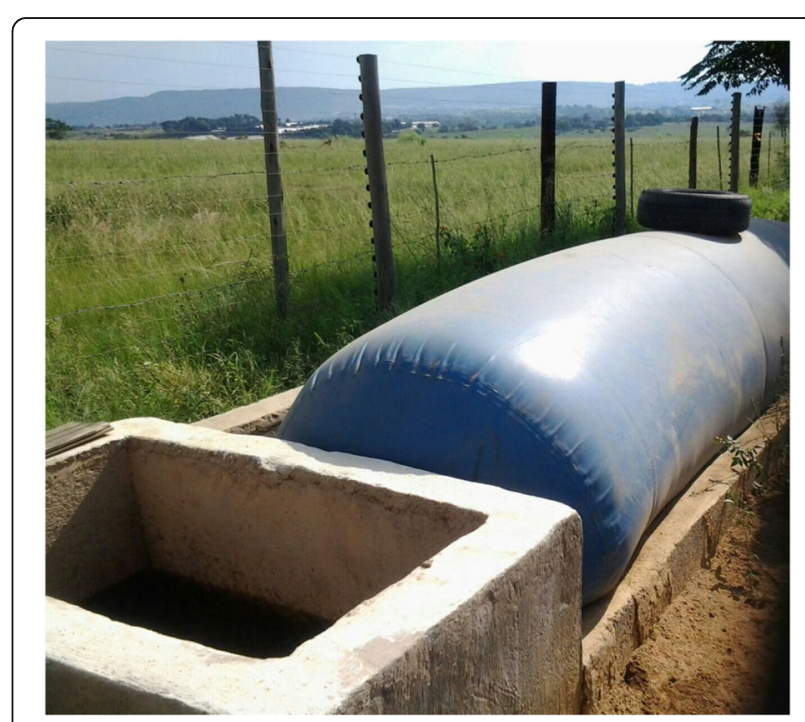

Fig. 3 Typical operational biodigester at the small-scale farm in Muldersdrift, Johannesburg, South Africa 
Africa. Some of the questions concerned the energy sources currently used by each respondent and the problems connected with employing them. One of the key questions asked concerned the respondent's access to feed, water and the transportation of biodigester feed. It was also important to establish the main incomegenerating activities of each participant, as well as his or her ability to maintain the digester. Other questions involved the capability of the participant to adhere to the safety regulations for biogas use and his or her keenness to learn more about the technology.

\section{Results}

\section{Results of surveys from Science Expos}

The survey conducted at the science events revealed that less than $10 \%$ of the high school pupils interviewed had any knowledge of biogas technology. What was also very surprising was their resistance to the concept. Most students said that the technology was not possible and also not "ethical". These students were concerned about the source of the biogas. They thought that since it is made from manure (or worse, sewage), it could be contaminated, and use of the biogas could cause illness. The local farmers surveyed also appeared to have little knowledge of the biogas technology, but in contrast, they were very willing to learn and implement it if it offered any benefit to them. An important aspect for the farmers was their wish to see a working biodigester unit and also to have a clear understanding of the economics concerned before they implemented the technology. At the science event in Sasolburg 2016, students from 7 out of 46 schools survey had knowledge of biogas. Although Sasolburg is industrialized, and the community in the area seemed to have some awareness of biogas, they still lacked information about it and had had no exposure to this technology.

\section{Results of the Muldersdrift case study}

Initially, $64 \%$ of the respondents including the owner of the farm on which the biodigester was located had no knowledge about the nature and application of biogas while the balance knew about biogas. The remainder had seen programmes on the subject on television, while others had read about it.

It was clear from the data that there is also lack of proper structures that can help to inform people about the advantages of using biogas because the majority of respondents to the first survey had no knowledge of this technology. This is especially true in rural areas where people have access to the required waste materials.

Also, information on biogas is mostly available only to researchers, not the potential users of this technology. This poses the need for us to bridge the process of turning the technology and research into practice in South
Africa. The opinion expressed by SABIA on this issue is that in order to boost the public's awareness and understanding of the biogas technology in South Africa, a great deal of financial support will be required [12]. This has not so far been forthcoming.

The case study found that after the educational process, most community participants indicated that they would adopt the technology if it would save them more time and money than the sources of energy currently available to them. Our analysis of the case study results showed that there were a number of key themes that emerged from the answers of most of the respondents.

\section{Community survey pre-installation Key themes}

These themes are discussed individually below and are based on pre- and post-implementation responses.

\section{Feedstock availability}

It was clear from the survey data that there was a pervasive perception that biogas technology works only for people who have sufficient animal and agricultural waste available to them to obtain a reasonable quantity of gas for energy. This perception is definitely not unfounded. However, crop production and animal husbandry are predominant in the rural areas and farms, so this section of the population can find ways to tap into this supply of material. About $68 \%$ of respondents, many of them, farm labourers or workers in the area, mentioned that although they did not own livestock, they were willing to travel to collect animal waste from neighbouring farms.

\section{Hygiene-related concerns}

Many of those surveyed expressed concern that biodigestion is unhygienic, as one uses smelly and bacteriainfested waste to produce energy. Although the preimplementation data was not quantitatively recorded, more than $50 \%$ of the people surveyed after the science events expressed worry and doubt that biogas was hygienically acceptable. They feared that they would be exposed to contact with the (dangerous) bacteria in the waste material, for example while preparing the slurry feed for the digester, or during cooking, and that this would be harmful to their health.

However, after the installation, most of the people who had seen how the technology worked had accepted that it posed no health risk. Figure 4 shows that $88 \%$ of the respondents do not have any concerns about the hygiene of using biogas technology for cooking purposes. Although these data do not allow an accurate comparison of pre- and post-perceptions of the risks of changing to biogas, the researchers were confident that they had seen a positive change in mindset. 


\section{Hygienic concerns}

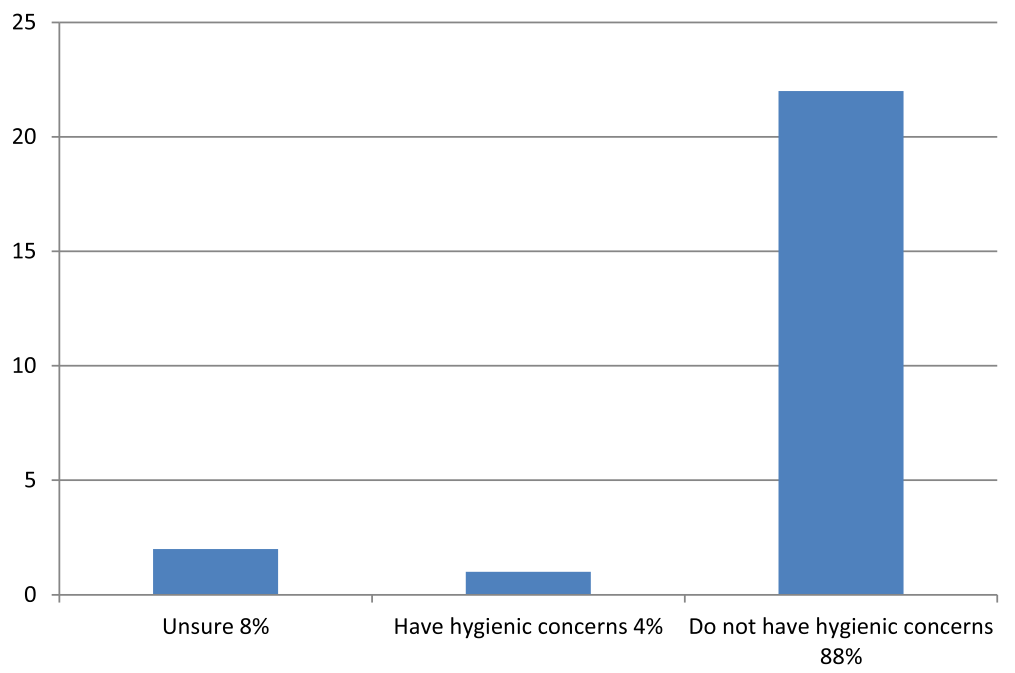

Fig. 4 Post-implementation: hygienic perceptions about the use of biogas post-implementation

\section{Access to energy}

Another prevalent theme raised in the pre-implementation survey was that community members are accustomed to using traditional energy sources like coal, paraffin and firewood and that they see no reason why they should shift to biogas.

The survey, as presented in Fig. 5, shows that $80 \%$ of the people in the community use electricity and paraffin as a source of energy. The owner of the farm where the digester was installed had used firewood, electricity, paraffin and LPG interchangeably for cooking. Currently, after the installation of the biodigester at the farm, 100\% of the farmer's energy supply for cooking comes from biogas, except in winter when gas production is low. Post-implementation, after seeing how the technology works, $92 \%$ of the respondents indicated that they would be willing to change from their traditional sources of energy to biogas for cooking (Fig. 6). Only one person indicated a refusal to change to biogas, preferring to continue using his current source.

\section{Cost}

A matter raised by most of the interviewees was that, while some of them see this technology as not practical, others are constrained from trying it only by a lack of the necessary building materials and knowledge of how

\section{Sources of energy currently used}

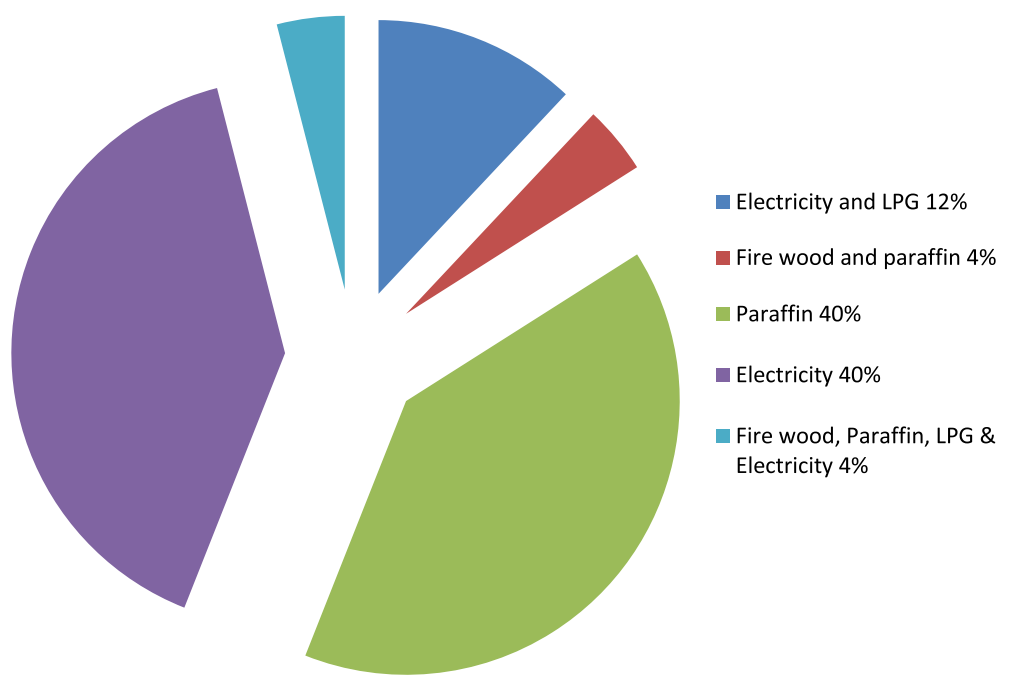

Fig. 5 Post-implementation: sources of energy currently used 


\section{Biogas adoption}

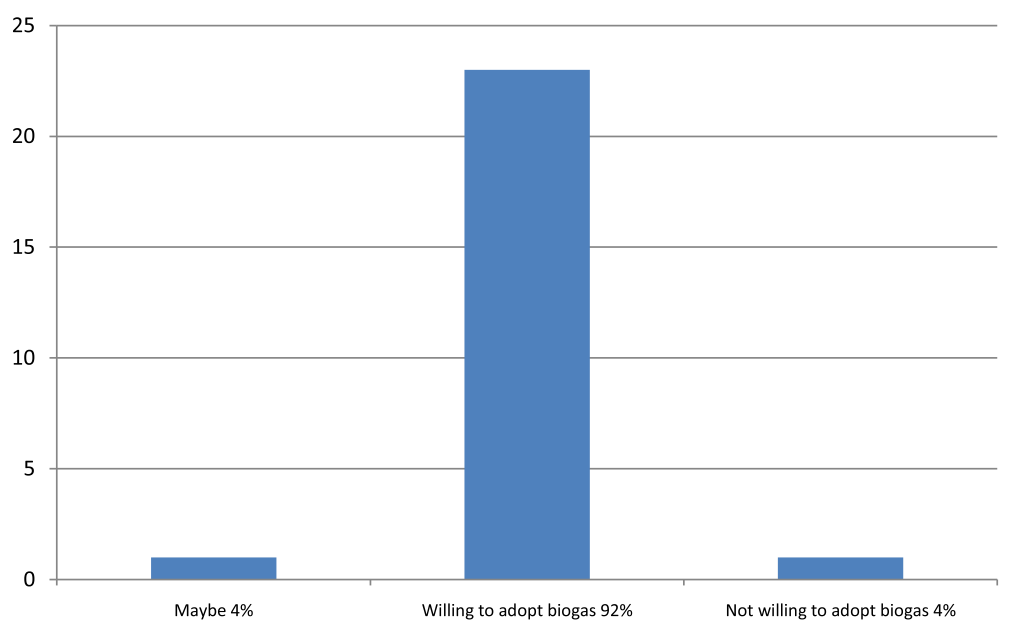

Fig. 6 Post-implementation: biogas adoption in relation to performance of technology

to implement the technology, and, most particularly, the means of meeting the capital costs of building such a structure.

The capital cost involved in purchasing and installing a biodigester presented a major challenge to the interviewees, although $92 \%$ of the respondents to the formal survey indicated that they were willing to adopt this technology. One respondent expressed a willingness to provide $50 \%$ of the capital cost, while another could raise only about $7.5 \%$ of the amount needed. None of them envisaged that the cost of maintaining the digester would present a problem.

\section{Safety and emissions}

Although the nature of biogas technology raises the possibility that a biodigester represents an explosion risk, generally biogas is a safe technology. The concentration of methane ranges from 40 to $70 \%$, which is low compared to the concentration in LPG gas $(90 \% \geq)$. The biogas inside a biodigester is usually at an operating pressure of around $2.5 \mathrm{KPa}$, low enough to avoid an explosion. If the biogas leaks from a small biodigester, the gas can become relatively diluted by the ambient air, as the biodigester is typically constructed in the open. The building/kitchen where the biogas is used needs to be well ventilated so that in the event of a leak, the gas is diluted. It is also assumed that if the user is able to follow the safety measures for using LPG gas, then he or she should be able to adopt and use biogas. The process is anaerobic, meaning that it occurs in the absence of oxygen; thus, as long as the pressure in the digester is higher than atmospheric pressure, the chances of an explosion are reduced as oxygen is required for combustion. In general, biogas is lighter than air and hence escapes into the atmosphere in the event of any leaks; whereas, even small leaks of LPG gas, which is heavier than air, can lead to an explosion. After practical demonstration through the building of the biodigester, $84 \%$ of the respondents to the survey perceived the handling and use of biogas technology as easy and safe. The relevant appraisals are summarized in Fig. 7.

In addition, communities need to be educated regarding the fact that $99 \%$ of the pathogens and bacteria in the feed are destroyed in the digester under anaerobic conditions, making it safe to handle the bio-slurry (also referred to as bio-fertilizer), which can be used for vegetable farming. Furthermore, the biogas is effectively bacteria-free and is thus safe to use. The smell that may come from the gas comes from sulphur-containing compounds and can be controlled by passing the gas through iron filings, leaving an odour-free, clean-burning fuel.

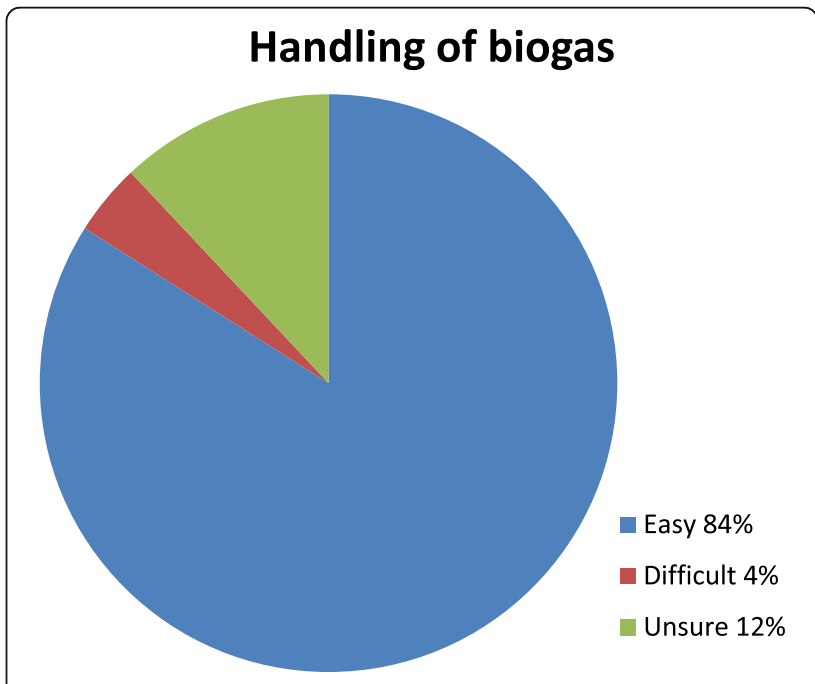

Fig. 7 Post-implementation: handling of biogas after exposure 
However, in the pilot demonstration, the farmer reported that there was no odour from the manure nor were any operational problems connected with the entire process.

\section{Age group and profession survey}

Figure $8 \mathrm{a}, \mathrm{b}$ compares the different ages of the people surveyed, and the nature of the work they do in the community. Sixty percent are workers, in jobs ranging from self-employed, farm or lodge employees, or people doing piece jobs. Twenty percent are farm owners, and the remaining $20 \%$ are unemployed. Thirty-one percent of the respondents were aged between 31 and 40 years while $50 \%$ were above 40 years old.

\section{Summary of results}

Overall, the survey indicated that two issues remained problematic.

- Feedstock availability: Many respondents felt that only those with access to fairly large numbers of feedstock whose numbers remain consistent can benefit from this technology. Consequently, biodigestion was seen to be most suitable for farmers or farm workers.

- Cost: The majority continued to believe that the capital costs of installing a biodigester are too high. This may be a challenge that needs to be addressed by government and entrepreneurs. For example if biobag biodigesters could be manufactured in South Africa, that might drive down the cost to more affordable levels.

These responses were similar to those found by Matsvange [10], who carried out research on changing to biodigestionat different locations in Zimbabwe. The findings were that people are willing to adopt the technology if the questions of availability of feedstock and cost were addressed.

\section{Discussion}

Based on surveys and the answers of the respondents, our research team has elicited that education and 'hands-on' exposure to biodigestion have a positive effect on the adoption process. A clearer understanding of biogas technology will impart greater confidence in potential users, which will increase the likelihood that the technology will be adopted. This in turn will be supported by noticeable benefits, as suggested by many other researchers. These include less time spent on gathering energy sources for cooking, thereby freeing up time for other activities; reduction in deforestation, a cleaner cooking process.

The benefits of lighting, cooking and time efficiency mentioned in the literature were actually demonstrated in our research by the reports of the recipient of the biodigester. Although research has also shown that the initial (and most important) barrier to adoption of biogas technology is lack of knowledge; other constraints emerged once that knowledge had been imparted.

The barrier of capital costs is formidable: researchers and government need to work together to make cheaper digesters available and to supply financial support to enable households or communities to build biodigesters. The energy consumed by the two-plate stove at Muldersdrift farm was rated at $2000 \mathrm{~W}$. It was used on average for $2 \mathrm{~h}$ per day for 30 days a month. The price of electricity, as set out in the electricity tariffs for the 2014/15 Mogale City Local Municipality, was ZAR 1.5423/kW h [20]. The total amount saved by changing to biogas per year is ZAR2 220.91 (approximately USD \$155, using an exchange rate of 1 USD: 14.34 ZAR-December 2016). To extrapolate, after 15 years, an amount of ZAR33.313.68 (USD \$2325) can be saved, using as a template the cost of cooking by electricity. More savings can be achieved if the calculations include power for lighting and geyser and generator usage. Although the capital cost of the imported biobag kit is a once-off amount of ZAR16 000 (USD \$1120), and the

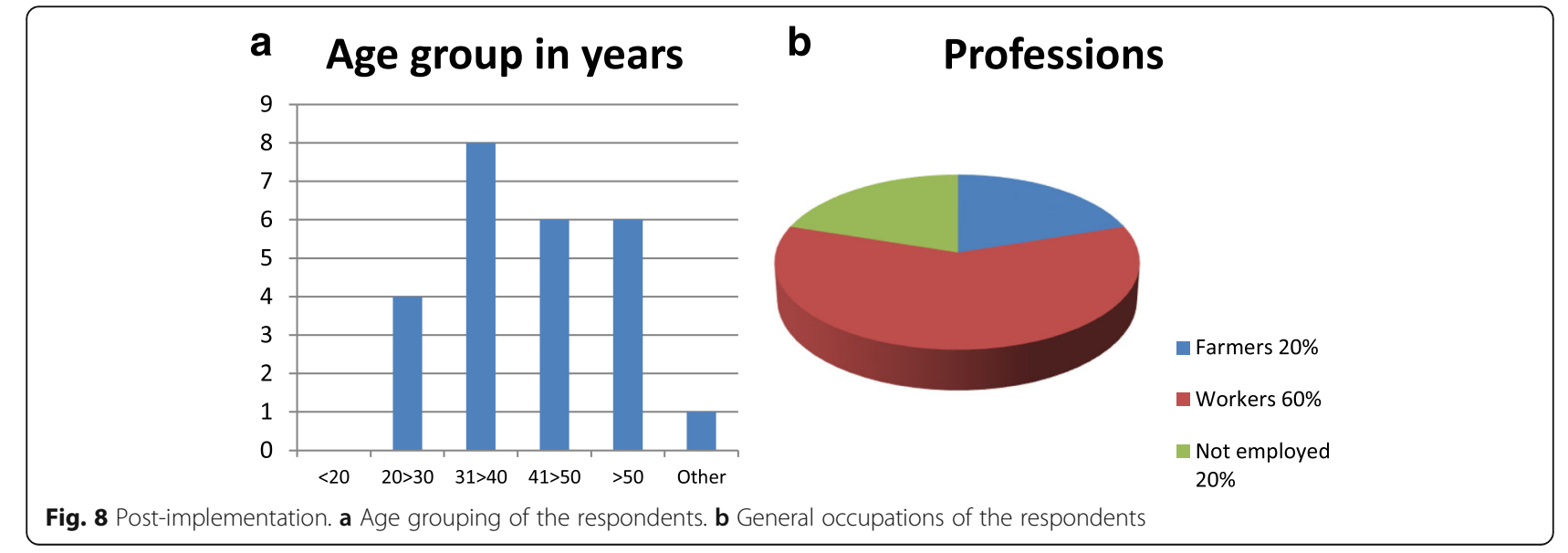

b Professions 
construction costs are around ZAR 5000 (USD \$350), the use of biogas has a long-term cost benefit, as the analysis of cost saved shows. This cost benefit will be enhanced if the bag can be produced more cheaply locally, or if less profit is made on the sale. The results of this case study show that if biogas use was adopted on a large scale, a sustainable bio-based economy is attainable.

Although this study was carried out in one location, which may limit its general applicability, it was clear from the post-implementation survey in the Muldersdrift community that there had been a complete shift in attitude after the local farmers had seen a biodigester constructed and put to work. This then suggests there is a need to roll out more digesters in similar rural societies.

However, this initiative faces barriers other than acceptance of biogas digestion by the targeted communities. The introduction of a new technology requires policy support from South Africa's government, which itself needs to understand how biodigestion works, and what potential it has to improve the lives of ordinary Africans. To date, there is very little, or no, information available on how much the country's decision-makers and even average South Africans know about biogas, or biogas technology. Unless provision is made to educate both the authorities and the public on the advantages of changing to biogas and to demonstrate that biogas technologies are safe and secure, there can be little hope that the necessary policy framework and start-up financing will be provided by the government. This would probably involve training a number of facilitators who can help the public to become aware of and assimilate the working and nature of biogas production.

At present, despite intensive planning and the efforts made by the Department of Trade and Industry (DTI) and other stakeholders, we continue to lack an adequate regulatory structure to support a large-scale launch of biogas technology [12]. According to the Department of Energy, the owner of a biogas project is required to register with the National Energy Regulator of South Africa (NERSA), which requires that the owner conform with multiple environmental regulations. These in turn have resulted in complex zoning legislation that must be complied with before any waste to energy biogas projects can be initiated [21]. At present, South Africa has no legal or policy guidelines to facilitate registration with NERSA, or to simplify compliance with zoning regulations. Another obstacle is the intricate administrative processes currently needed for project development and authorisation, especially at municipal level.

In order to tackle these issues, various stakeholders, including the Department of Energy (DEO), have begun to draft a policy framework for the installation of biodigesters in remote regions of South Africa and to identify rural households that would be able to use one.
Accordingly, the framers of the policy should aim to take into account the availability of suitable feed, water and finance in the case of each recipient, as the biodigester should be sustainable in terms of cost. The last is of vital importance. At present, South Africa's government does not make any provision to fund, or create, dedicated financial mechanisms, incentives and grants to assist the adoption of biogas. The most serious obstacle to supplying digesters to the rural poor is the capital outlay required to buy and install them.

Some progress has been made. Currently, a committee is being set up to consult on legal issues relating to the registration, certification and licencing of rural biodigesters. Yet despite the advances made in policy in recent years, there remains a gap that needs to be filled.

\section{Conclusions}

This research has shown that education and exposure are the key tools required to help increase the adoption of biogas in rural and small-scale farming areas. The judicious use of these tools (education and exposure) could help unlock the enormous promise that we can build a bio-based economy, in by these means alleviate poverty in rural South Africa, both as far as energy provision and a better standard of living are concerned. The findings also show that a successful collaboration between research and community engagement can generate knowledge and skills that can be transferred to help a community to adopt biogas as a form of renewable energy. We also recommend that government should play a role in disseminating biogas technology as a renewable source of power in rural areas. This would help to promote greater awareness of the technology, which in turn would expand its adoption. The construction of pilot digesters in rural communities will also expose the members of that community to the practical advantages of this technology, and thus help them to enjoy its benefits.

It is important that policy makers should note that education is the driving force because it can erase misconceptions. There is therefore a need for the government to provide platforms for learning and demonstration of biogas technology in order to support and expand the application of this sustainable form of energy.

\footnotetext{
Acknowledgements

The authors would like to thank The University of South Africa's Community Engagement Department for the financial support that made this research possible. They also express gratitude to the Materials and Process Synthesis Research Unit and Engineers Without Borders, South Africa for the technical support given during the research and the implementation of the projects. Also special thanks are due to the UNISA student members who contributed their knowledge and sacrificed time to construct the digesters, which made it possible for us to collect the information contained in this paper.
} 


\section{Authors' contributions}

RFM was involved in installing the biodigester and carrying out the social research, and he was involved in the writing and editing of the paper. $\mathrm{DH}$ was responsible for writing and editing the research work, and she is also the project leader for this research work. LN was responsible for writing and editing the research work, and he was hands on during the conceptualisation of the research project. TM was responsible for writing and editing the research work. NC was responsible for carrying out the actual research work as well as research writing and editing. All authors read and approved the final manuscript.

\section{Authors' information}

Ralph Farai Muvhiiwa is a chemical engineer by profession and is the Chairperson for Engineers Without Borders at the University of South Africa. He heads the community engagement flagship by trying to put engineering knowledge into practice.

Diane Hildebrandt is a professor in Chemical engineering.

Lwazi Ngubevana has a doctorate in Chemical engineering.

Tonderayi Matambo has a doctorate in Biotechnology.

Ngonidzashe Chimwani has a doctorate in Chemical engineering. He is

currently an active member of Engineers Without Borders.

\section{Competing interests}

The authors declare that they have no competing interests.

\section{Publisher's Note}

Springer Nature remains neutral with regard to jurisdictional claims in published maps and institutional affiliations.

Received: 14 June 2016 Accepted: 1 June 2017

Published online: 29 June 2017

\section{References}

1. Musyani Gavin Chewe (2013) The emerging biogas industry in South Africa-what opportunities? Integrated Sustainability services (ISS), February 15, 2013. http://iss-za.net/page2col.php?page=24\&section=76. Accessed 8 Nov 2015

2. Triebel R, Damm O (2008) A synthesis report on biomass energy consumption and availability in South Africa. A report prepared for ProBEC.

3. Munganga G (2013) Overview of biogas market in South Africa. http://www. energy.gov.za/files/biogas/presentations/2013-NBC/2013-Overview-of-biogasmarket-in-South-Africa.pdf. Accessed 11 Nov 2011

4. Tiepelt M (2015) South African international renewable energy conference. http://www.sairec.org.za/wp-content/uploads/2015/10/M-Tiepelt-SAIREC Conference.pdf. Accessed 11 Nov 2011

5. Le Ha Chau (1998) Biodigester effluent versus manure from pigs or cattle as fertilizer for production of cassava foliage (Manihotesculenta) livestock research for rural development. Volume \# 10, (3) http://www.fao.org/ag/ aga/agap/frg//rrd//rrd10/3/chau1.htm. Accessed 15 Oct 2015

6. Johansson Kajsa (2008) Biogas residues as fertilizers effects on plant growth and soil microbiology. Report, Dept. of Microbiology, SLU, Uppsala

7. Nørgaard Anna Dorte and TybirkKnud (2014) Scandinavian biogas handbook: aspects of planning a biogas plant. Agro Business Park, Denmark

8. Cassie B, DiLeo M, Lee J (2010) Methane creation from anaerobic digestion. In: Thompson R (ed) Worcester Polytechnic Institute., p 59

9. Pal S (2002) Evaluation study on National Project on Biogas Development (NPBD), renewable energy, domestic biogas. Monitoring \& evaluation, New Delhi, India, pp 1-105

10. Matsvange D, Sagonda R, Kaundikiza M, Zaba P (2016) Biogas technology diffusion and adoption mechanisms in Zimbabwe. Africa Insight 45(4):148-166

11. Kenya domestic biogas user survey (2014). http://www.snv.org/public/cms/ sites/default/files/explore/download/biogas_users_kpt_survey_-_kenya_final_ report_oct_2014.pdf. Accessed 8 Nov 2016

12. South African Biogas Industry Association (SABIA), National Biogas Conference, Standards and Regulations 5 March 2015.

13. Jones R (1995) Why do qualitative research? Br Med J 311(6996). p 2

14. Newman I, Benz CR (1998) Qualitative-quantitative research methodology: exploring the interactive continuum: SIU Press, Science. p 218

15. Bryman A (2012) Social research methods, 4th edn. Oxford University Press, United States

16. Johnson B, Christensen L (2012) Educational research: quantitative, qualitative and mixed methods, 4th edn. SAGE Publications Inc., California
17. Blankenship DC (2010) Applied research and evaluation methods in recreation. Library of Congress Cataloging-in-Publication Data, United States of America

18. Fox JA, Hildebrandt D, Glasser D, Patel B (2013) A graphical approach to process synthesis and its application to steam reforming. AICHE J 59(10):3714-3729

19. Seadi TA, DominikRutz HP, Köttner M, Finsterwalder T, Volk S, Janssen R (2008) Biogas Handbook. Esbjerg, Denmark, pp 23-25

20. Mogale City (2014) http://www.mogalecity.gov.za/residents-154/tariffs. Accessed 11 Nov 2015

21. Ruffini A (2013) SA not using its biogas potential. Africa Powers Journal http://www.esi-africa.com/sa-not-using-its-biogas-potential/. Accessed 15 Oct 2015

\section{Submit your manuscript to a SpringerOpen ${ }^{\circ}$ journal and benefit from:}

- Convenient online submission

- Rigorous peer review

- Open access: articles freely available online

- High visibility within the field

- Retaining the copyright to your article

Submit your next manuscript at $>$ springeropen.com 